\title{
Study on Higher Vocational English Teaching Model Based on Network Platform
}

\author{
Hongjuan Li \\ Tianjin Maritime College Tianjin 300350
}

Keywords: Network platform; Higher vocational education; English teaching; Teaching model

\begin{abstract}
With the continuous development of network technology, higher vocational English teaching mode has opened the path of innovative exploration. This paper focuses on the higher vocational English teaching and the advantages of Higher vocational English teaching mode under the network platform based on some suggestions, hoping to help the majority of English teachers in Higher Vocational Colleges to improve teaching efficiency.

In the context of global integration, as the world's first common language, English is a way of China go to the world. Therefore, English teaching has been paid more and more attention and the reform of English teaching mode has received more and more attention. Higher vocational colleges must realize the advantage of the network platform for English teaching with making full use of network platform which is a new teaching equipment to improve the overall quality of vocational English teaching, and promote students to improve the standard of English.
\end{abstract}

\section{Higher Vocational English Teaching under Network Platform}

The progress of science and technology provides great convenience to people's life, but also has brought a lot of changes to the people's production and life, the network platform occupies an important position in the teaching which has become the inevitable trend of social development, therefore, we should give full play to the advantages of network platform in higher vocational English teaching to provide better service for higher vocational English teaching.

\section{Advantages of Network Platform in Higher Vocational English Teaching}

Rich Resources. The biggest advantage of network platform lies in its rich resources. The network platform makes full use of the Internet with the vast resources of Internet and multimedia database, and the advantages of providing more abundant teaching resources for students to help students to learn English pronunciation, English grammar, and English is the most accurate and most interesting programs and most authentic English speaking countries. The rational use of the network platform can enhance students' learning enthusiasm, and stimulate students' interest in English, and broaden their horizons, and help students with English listening, speaking, reading and writing. At the same time, the openness of the network platform also gives students the convenience of learning English for free with reducing the cost of learning English and reducing the burden on students' families.

Various Forms. Rich resources of network platform have different expression form. Through the network platform, teachers and students can find a variety of information helpful to English teaching, including text, pictures, video, audio, animation and so on. These teachers will download the data to be classified, screened, selected flexibly according to the needs of teaching, and teachers can better achieve the goal of teaching to avoid the pure knowledge in the classroom, make the classroom more lively and interesting. In addition, the teachers with ability can also according to their own knowledge through the software design more different forms of expression to help vocational English classroom teaching. This colorful phenotype is more easily accepted by students, and students tend to be more profound memory.

Save Time. Compared with the traditional teaching of writing, teaching method based on network platform can save more time for writing teachers to reduce the time spent on the key and difficult to extend the knowledge of the time, to enable students to grasp the knowledge points more 
clearly. In addition, teachers can also print out the courseware before class distributed to students in the classroom. When learning courseware, the students in the classroom will focus on the timely annotation that can also save some, students taking notes of the extra time can be convenient for students to ask more questions, and let the teachers to answer their doubts to improve their English achievement. In the classroom, to save more time, whether for teachers or students have a great benefit to enhance vocational school English classroom teaching efficiency.

\section{The Role of Network Platform in Higher Vocational English Teaching}

Promote Friendly Interaction between Teachers and Students. The traditional English teaching model is that the teacher standing on the podium, to give his knowledge students with few interactive links, so that students cannot express their true thoughts at the podium, and the learning is very passive. Once the teacher's explanation is a bit boring, students will have drowsy feeling, and the teaching efficiency will be overall low. But in the network platform, English teaching model is more equality between teachers and students in exchanging questions, teachers should be strengthened, and students can always express their views to enhance the enthusiasm and initiative of learning English, students English level. In addition, in the English teaching network platform, students and teachers make full use of English chat rooms, forums, E-mail, English and other English learning websites which can help English learning platform where teachers and students showed great enthusiasm for English constantly keeping a fresh feeling to improve the English teachers' teaching effect and students' learning efficiency.

Promote the Development of Students' Personality. In higher vocational English teaching, making full use of various resources, the network platform is enable the student to obtain happiness and satisfaction in learning, help students in English class who will to work hard to learn English to improve the efficiency of English Teaching in Higher Vocational colleges. In the actual classroom teaching, teachers can depend on the characteristics of the class students, the flexible choice of teaching resources, so that each student can find the most suitable for their own learning methods. As the saying goes, interest is the child's best teacher. Compared with the cramming teaching method and students are forced to learn the teaching mode based on the network platform, according to the student's own interests, helping students grasp the individualized teaching methods of English knowledge can be respected and liked by the students. It can not only make English knowledge easier for students to accept and recognition, but also to promote the development of students personalized, so that each student can realize their own characteristics.

Improve Students' Interest of Learning. The students in Higher Vocational Colleges are mostly at the age of eighteen or nineteen, it means in the golden age of life. They are curious about the world, and eager to explore the world. The network platform can be closely linked to the world, and through the network, unwilling to do a student can see the colorful world developing a vision of the growth of knowledge, therefore, they generally will be more interested in the English curriculum based on network platform, reduce truancy rates, and listen carefully in class to improve the efficiency of learning. In this case, students will spend more time in English learning to improve the overall learning atmosphere.

\section{Suggestions on Higher Vocational English Teaching Model under Network Platform}

Since the network platform based English teaching model has so many advantages, so it is necessary to change the existing Vocational College English teachers' teaching model to make full use of network platform, and make their English classroom full of vitality to create a more favorable environment for students in English class.

Rational Use of Network Resources to Create Teaching Environment. Generally speaking, foundation of the higher vocational college students is relatively weak, who is not very interested in English, which means learning enthusiasm is relatively low, and the lack of initiative in learning English requiring a lot of time in the encouragement and supervision of teachers be reluctant to learn. In view of this situation, teachers need to classify and manage a large number of resources on 
the network, and according to the general character of the students, to judge the interests of the students, and then fully according to the teaching content reform of classroom teaching. In order to attract students' interest, teachers can add a lot of pictures and interesting knowledge in teaching courseware, when necessary to add some audio or video to attract students attention to create a relaxed classroom atmosphere, then the teachers gradually adding the knowledge that students can accept in the course. The students' English proficiency improved imperceptibly.

Rational Use of Network Platform, Comprehensive Teaching Evaluation. At present, vocational colleges teaching and learning evaluation mechanism is usually at the end of the year, the final exam scores of a summary and evaluation of students, ignoring the daily performance of the student in the school period. This way has a big defect, which cannot fully examine the comprehensive level and overall quality of students, teachers and students are biased. In this case, the advantages of the network platform will be revealed.

English teachers can use the network platform to carry out a comprehensive assessment model of learning evaluation for students, the daily performance of students usually results in the mid-term and final exams combining on students' English learning is a comprehensive multi-angle evaluation. At the same time, teachers can give students some evaluation every day after class evaluation. It is the implementation of students find their progress encourage students to better learn English. In addition, it also can let the students help teachers to realize the preparation and lecture in the deficiencies through the curriculum evaluation network platform for teachers to improve English teaching and study.

Rational Use of Network Interaction, Group Learning. In the traditional class teaching model, there are many deficiencies lead to teachers cannot clearly see the existence of every student in the learning process, and in the situation, students are often not fully grasp. In this case, the teacher can be in accordance with the degree of learning in the network platform for group teaching, and the number of members can depend on the specific circumstances. Team members can help each other by common discussion, and teachers can better grasp the level of the students according to the overall level of the group and specific conditions for students to develop different learning plan, encourage students to progress together with the lack of large classes offset to some extent.

Rational Use of Network Resources, Promote the Development of Personality. The network platform is more individualized in teaching model to enable each student to obtain more personalized development to avoid the plight of school factory. Therefore, teachers need to make rational use of network resources according to each student's interest in teaching. For example, some students love fashion, and teachers can find some English fashion magazine resources, so the students will translated it into Chinese by training students' reading and translating ability; while some students love movies, teachers can let students watch the English film soundtrack, and let the students be part of the translation of film dialogues in Chinese by exercising and listening the translation ability of students and so on. These methods pay more attention to the cultivation of students' skills, so that students get knowledge in entertainment, broaden their horizons and enrich the classroom.

Rational Use of Teaching Platform, Perfect the Teaching System. There are all kinds of network platform resources, some conducive to learning content which means there must be to learn harmful content, even some resources are not scientific and health for students learning with life harm. At this point, teachers need to improve the teaching system, screening the network resources, and leaving the content suitable for students to learn, so that students can learn English better. In addition, the network teaching can be used in the daily classroom teaching, so that students can better grasp the network technology to meet the needs of society.

Rational Use of Network Interaction, Combination of Home Leaning and School Learning. Teachers and students can build a chat group on the network platform, which is a good interaction, if students have problems on English at home, he can ask the teacher directly through the network platform for the first time to reduce time on the problem of students stay in the heart, and this can effectively avoid forgetting of the students, it can be realized that perfect combination of home leaning and school leaning can promote students' achievement. 


\section{Conclusion}

In summary, English is an important course which requires the leadership of teachers and students in higher vocational schools attach the importance. The construction of the network platform will help to improve the English teaching environment, and promote teachers' teaching level to improve students' learning efficiency, so that between students and teachers, there will be more closely linked forming the benign interaction and jointly promoting English teaching.

\section{References}

[1] Hongyun Zhao. Research on higher vocational English teaching model based on Web technology platform [J].Campus English, 2016, 19: 76.

[2] Yibo Qu. Higher vocational English teaching model based on network platform[J].The Science Education Article Collects(Mid period),2016,05:76-77.

[3] Minjie Luo, Lutie Zhong. Study on higher vocational English teaching model based on network platform [J].Chinese Youth, 2016, 11: 195. 